\title{
Hormonal changes in female buffaloes under shading in tropical climate of Eastern Amazon, Brazil
}

\section{Jamile Andréa Rodrigues da Silva ${ }^{1}$, Airton Alencar de Araújo², José de Brito Lourenço Júnior ${ }^{3}$, Núbia de Fátima Alves dos Santos ${ }^{1}$, Rinaldo Batista Viana ${ }^{1}$, Alexandre Rossetto Garcia ${ }^{4}$, Davide Rondina², Márcia Mascarenhas Grise ${ }^{5}$}

\author{
${ }^{1}$ Universidade Federal Rural da Amazônia, Belém, PA, Brasil. \\ 2 Universidade Estadual do Ceará, Fortaleza, CE, Brasil. \\ ${ }^{3}$ Universidade do Estado do Pará, Belém, PA, Brasil \\ ${ }^{4}$ Embrapa Pecuária Sudeste, São Carlos, SP, Brasil. \\ ${ }^{5}$ Embrapa Amazônia Oriental, Belém, PA, Brasil.
}

ABSTRACT - The hormonal responses of 20 female buffaloes raised under the sun (SS group) or in the shade (CS group) in Belém, Pará, Brazil, were assessed. The CS group $(\mathrm{n}=10)$ was kept in a silvopasture system featuring Racosperma mangium, whereas the SS group $(\mathrm{n}=10)$ was kept in paddocks without shade featuring Brachiaria humidicola, drinking water, and mineral salt. The following parameters were measured for each treatment: dry-bulb temperature (AT), relative humidity (RH), and black-globe temperature in order to calculate the globe temperature and humidity index (GTHI). Blood sample collections to quantitatively determine levels of cortisol, triiodothyronine $\left(\mathrm{T}_{3}\right)$, and thyroxine $\left(\mathrm{T}_{4}\right)$ were performed every 14 days, at $13.00 \mathrm{~h}$. Different seasons of the year were also assessed: rainy (January-April), transition (May-July), and less rainy (August-December). Analysis of variance revealed that AT and the index of global temperature and humidity (GTHI) differed between groups; specifically, higher values were found in the SS group, which shows how important silvopastoral systems are in buffalo farming in tropical climates. Relative humidity was significantly different across seasons and particularly high in the rainy season. The treatments influenced cortisol such that higher values were observed in the SS group. The highest mean cortisol levels were recorded during the rainy and less rainy seasons, whereas the highest $\mathrm{T}_{3}$ and $\mathrm{T}_{4}$ levels were recorded only during the rainy season. Triiodothyronine and thyroxine were negatively correlated with AT and GTHI and positively correlated with RH. Silvopastoral systems provide thermal comfort to buffaloes, and the less rainy season is more likely to cause heat stress.

Key Words: bioclimatology, cortisol, ruminant, silvopasture system, thyroid hormone

\section{Introduction}

The Eastern Amazon region is characterised by a hot and humid climate, with a mean air temperature (AT) of $26.8{ }^{\circ} \mathrm{C}$, a relative humidity $(\mathrm{RH})$ of $83 \%$, and rainfall of 2,876.9 mm each year (Pachêco et al., 2009). Given these climatic conditions, buffalo production is satisfactory across the different native grassland ecosystems and cultured in dry land and floodplains. However, buffaloes can become stressed when exposed to high temperatures and direct sunlight, which consequently decreases their productive and reproductive performance. Thus, the adoption of production systems such as the silvopasture system (SPS) is important because the trees located in the pasture decrease the intensity of direct solar radiation, thereby providing greater thermal comfort and hence more productive buffaloes (Castro et al., 2008; Moraes Júnior et al., 2010).

The thyroid and adrenal glands play important roles in animal adaptation. The concentration of thyroid hormones and the production of metabolic heat decrease (Morais et al., 2008), whereas the blood concentration of cortisol increases (Marai and Haeeb, 2010) under heat stress. Thus, studying the variations in the concentrations of the thyroid and adrenal hormones is of utmost importance to determine the influence of heat stress on animal metabolism (White, 2009; Marai and Haeeb, 2010; Haque et al., 2012).

Given the limited amount of hormonal information concerning heat stress with regard to female buffaloes in the Amazon, the objective of the present study was to research the thermal-stress-indicating hormonal profile of these animals, raised in traditional and silvopastoral production systems in the Eastern Amazon, Brazil.

\section{Material and Methods}

The current experiment was conducted at the Animal Research Unit Senador Álvaro Adolpho $\left(01^{\circ} 26^{\prime} 03^{\prime \prime} \mathrm{S}\right.$ and 48²6'03" W), Embrapa Amazônia Oriental, Belém, Pará, 
Brazil, from January to December 2009. The climate type is Afi (Köppen), with an mean annual rainfall of $3,001.3 \mathrm{~mm}$, which is well distributed over the year (Silva et al., 2011). The rainy season ranges from January to June, and the less rainy season goes from July to December. The mean annual temperature is $26.8{ }^{\circ} \mathrm{C}$, with a mean $\mathrm{RH}$ of approximately $83 \%$ and an annual insolation of 2,279.6 hours (Pachêco et al., 2009). The soil type is yellow oxisol, stony phase I with clay texture.

Twenty 4- to 5-year-old female Murrah buffaloes were used, with a mean weight of $479.6 \mathrm{~kg}$. These animals were cyclical, non-pregnant, non-lactating, and clinically healthy. Furthermore, they were randomly divided into two groups: with shade (CS) and no shade (SS). The CS group $(\mathrm{n}=10)$ remained on paddocks under the SPS featuring Brachiaria humidicola and shade provided by the leguminous tree Racosperma mangium. These trees were planted 4 metres apart in the perimeter with electrified divider fences featuring two strands of smooth wire (Moura Carvalho et al., 2001). The SS group $(n=10)$ was kept in paddocks with the same feed management but without access to shade. Both groups were kept under intensive rotational grazing, with a stocking rate of $1.78 \mathrm{AU}^{-h^{-1}}{ }^{-1}$ as well as access to drinking water and mineral salt ad libitum. Sanitary prerogatives with regard to vaccinations and parasite control were followed according to Láu (1999).

The climatic data during the experimental period were recorded using a heat-stress meter (Instrutherm, TGD-300 model) installed in the microclimate of the paddocks for both CS and SS. The following variables were recorded: AT (maximum, mean, and minimum), RH, dew-point temperature, and black-globe temperature. The environmental variables were recorded between $12.00 \mathrm{~h}$ and $13.00 \mathrm{~h}$, twice a week, when the physiological variables were collected. After the data were recorded in the data logger, the calculated variable means were collected each minute. The environmental index (GTHI, as proposed by Buffington et al., 1981) was determined using the following formula:

$$
\mathrm{GTHI}=\mathrm{BgT}+0.36 \mathrm{DpT}+41.5,
$$

in which $\mathrm{BgT}=$ black-globe temperature under the sun $\left({ }^{\circ} \mathrm{C}\right)$, and $\mathrm{DpT}=$ dew-point temperature $\left({ }^{\circ} \mathrm{C}\right)$.

The blood sampling to determine the levels of cortisol hormones, triiodothyronine $\left(\mathrm{T}_{3}\right)$, and thyroxine $\left(\mathrm{T}_{4}\right)$ was performed every 14 days at the peak local ambient temperature $(1 \mathrm{pm})$ via a puncture of the jugular vein using vacutainer tubes without anticoagulant. The samples were centrifuged at $2,500 \mathrm{rpm}$ for 20 minutes. Plasma aliquots were stored at $-20{ }^{\circ} \mathrm{C}$ until the time of hormonal dosage at the Clinical Analysis Laboratory of Universidade de Fortaleza (UNIFOR), Ceará, Brazil. The quantitative hormone determination was performed using commercial kits and analysed via the AXSYM $^{\circledR}$ system (Abbott). Microparticle Enzyme Immunoassays (MEIA) were used for $\mathrm{T}_{3}$ determination with an analytical sensitivity of $\leq 0.3 \mathrm{ng} / \mathrm{dL}$. Thyroxine $\left(\mathrm{T}_{4}\right)$ and cortisol levels were determined using fluorescence polarisation immunoassay (FPIA) with analytical sensitivities of 1.05 and $1.1 \mu \mathrm{g} / \mathrm{dL}$, respectively.

The hormonal and climatic data were expressed as means and standard deviations. The climatic data analysis of the microclimate treatments revealed a transition phase between the rainy and less rainy seasons from May to July that was accompanied by a significant decrease in $\mathrm{RH}$ and a significant increase in AT. Thus, the data were organised into three seasons: rainy (January-April), transition (May-July), and less rainy (August-December).

The experiment employed a completely randomised $2 \times 3$ factorial design: two treatments (with or without shade) and three seasons (rainy, transition, and less rainy). Data analyses were performed to determine the main effects of treatment and seasons, as well as their interaction, on hormonal variations using the Statistical Analysis System (SAS, version 8) software. Means were compared using Tukey's test at a probability level of 0.05 . Pearson's simple correlations were performed to verify the magnitude and direction of the proportionality of the hormonal variables and to observe pairwise independence.

\section{Results and Discussion}

The present work revealed thermal condition index values above comfort (GTHI>74), which shows that, in both treatments, the climate of the region causes thermal discomfort to the animals. The GTHI significantly differed across the seasons $(\mathrm{P}<0.05)$, with higher values during the less rainy season (Table 1). This finding was most likely due to the occurrence of high AT, which caused stress among the animals.

The highest mean cortisol levels were recorded during the rainy and less rainy seasons, and these levels were significantly higher than those found during the transition period. The highest mean RH occurred during the rainy season, which might have influenced the blood concentration of cortisol because RH favours the occurrence of ectoparasites such as haematophagous insects that disturb the animals, cause them stress, and interfere negatively with their metabolic processes (Bianchin et al., 2006).

The elevation of cortisol levels during the less rainy season was most likely due to the simultaneous increase in AT, which might have caused heat stress in the animals. The 
increase in this climate variable causes stress that acts on hypothalamic neurosecretory cells via the central nervous system (CNS) to secrete corticotrophin-releasing hormones (CRH). In turn, the $\mathrm{CRH}$ signal the pituitary gland to release the adrenocorticotropic hormone (ACTH), which acts at a distance and releases the adrenal gland hormones. Corticosteroids, especially cortisol, are produced in the adrenal cortex (Marai and Haeeb, 2010; Garcia, 2013).

During the transition period, the animals were under thermal comfort given their cortisol levels during the other seasons. This result indicates that the climatic conditions of the transition period favour the raising of buffaloes, although this species showed successful performance in other seasons.

The highest mean $\mathrm{T}_{3}$ values were recorded during the rainy season, and these values were significantly higher than those found during the transition and the less rainy seasons, most likely because of the higher AT during the rainy season (Table 1). The decrease in $\mathrm{T}_{3}$ concentrations in response to heat stress can act as an adaptive mechanism to reduce heat production (Marai and Haeeb, 2010).

The highest $T_{4}$ values occurred during the rainy and transition seasons most likely because feed intake and the concentration of plasma thyroid hormones decrease during less rainy season to reduce endogenous heat production (White, 2009). In India, Aggarwal and Singh (2010), while assessing hormonal changes in lactating Murrah buffaloes in two different cooling systems (sprinkling and immersion) in two periods of the year (hot-dry and hothumid), reported that $\mathrm{T}_{3}$ plasma levels did not vary between the periods studied or between the cooling systems. The mean values in the dry-hot period for the sprinkling and immersion groups were $1.97 \pm 0.03$ and $1.88 \pm 0.03$ ng. $\mathrm{mL}^{-1}$, while in the dry-humid period they were $1.83 \pm 0.04$ and $1.99 \pm 0.03$ ng. $\mathrm{mL}^{-1}$, respectively. Thyroxine $\left(\mathrm{T}_{4}\right)$ plasma levels varied between the periods studied $(\mathrm{P}<0.01)$; they were higher during the hot-dry period for the buffalos in immersion $\left(52.27 \pm 0.67 \mathrm{ng} . \mathrm{mL}^{-1}\right)$ than for the buffalos under sprinkling $\left(50.65 \pm 0.50 \mathrm{ng} \cdot \mathrm{mL}^{-1}\right)$. In the dry-humid period, the $\mathrm{T}_{4}$ values were $50.97 \pm 0.61$ and $48.25 \pm 0.54 \mathrm{ng} \cdot \mathrm{mL}^{-1}$, respectively.

A significant difference of treatment was also observed: the SS group presented higher values of GTHI (Table 2). This result emphasises the importance of using trees in management systems to provide greater thermal comfort for animals (Moraes Júnior et al., 2010; Silva et al., 2011) and improve their yield (Castro et al., 2008; Moraes Júnior et al., 2010; Garcia et al., 2011). Incorporating trees into pastures in hot, humid climate regions favors the microclimate and provides better thermal comfort conditions, since shading can lower GTHI compared with areas under full sunlight (Garcia, 2013).

Treatment influenced cortisol values; specifically, the SS group had significantly higher values. This result is most likely due to the increased sunlight exposure for the animals in this group. Previous research has shown that animals suffer from heat stress under high temperatures, thereby increasing the blood concentration of cortisol (Starling et al., 2005). Aggarwal and Singh (2010), assessing hormonal changes in lactating Murrah buffaloes in two different cooling systems (sprinkling and immersion) in two periods of the year (hot-dry and hot-humid), reported that plasma cortisol levels were higher $(\mathrm{P}<0.01)$ for buffaloes under sprinkling than for those in immersion $(4.80 \mathrm{vs.} 2.60 \mathrm{ng} / \mathrm{mL})$. On the other hand, the plasma cortisol levels of buffalos under sprinkling were higher in the dry-humid period (4.80 \pm 0.14$)$ compared with the hot-dry period $(4.33 \pm 0.16)$. In Thailand, aiming to measuring the effects of immersion on the performance and physiology of female buffaloes, Khongdee et al. (2011) reported that, in hot climates, immersion in water is enough to reduce cortisol levels $(3.55 \pm 1.53$ vs. $2.33 \pm 1.39 \mathrm{ng} / \mathrm{mL}, \mathrm{P}<0.05)$.

Table 1 - Index of global temperature and humidity (GTHI), blood cortisol and $\mathrm{T}_{3}$ and $\mathrm{T}_{4}$ levels of female buffaloes raised under the sun or shade

\begin{tabular}{|c|c|c|c|c|c|c|c|c|}
\hline \multirow{2}{*}{ Season } & \multicolumn{2}{|c|}{ GTHI } & \multicolumn{2}{|c|}{ Cortisol ( $\mu \mathrm{g} / \mathrm{dL})$} & \multicolumn{2}{|c|}{$\mathrm{T}_{3}(\mathrm{ng} / \mathrm{mL})$} & \multicolumn{2}{|c|}{$\mathrm{T}_{4}(\mathrm{ng} / \mathrm{mL})$} \\
\hline & Maximum & Mean & Maximum & Mean & Maximum & Mean & Maximum & Mean \\
\hline Rainy & 86.9 & $83.9 \pm 2.2 \mathrm{c}$ & 2.1 & $1.8 \pm 0.2 \mathrm{a}$ & 1.7 & $1.4 \pm 0.2 \mathrm{a}$ & 6.3 & $5.1 \pm 0.9 \mathrm{a}$ \\
\hline Transition & 91.4 & $87.6 \pm 3.1 \mathrm{~b}$ & 2.2 & $1.7 \pm 0.3 b$ & 1.3 & $1.1 \pm 0.2 b$ & 6.0 & $5.0 \pm 0.9 \mathrm{a}$ \\
\hline Less rainy & 92.0 & $88.8 \pm 2.6 \mathrm{a}$ & 2.3 & $1.9 \pm 0.3 \mathrm{a}$ & 1.2 & $1.0 \pm 0.1 \mathrm{~b}$ & 5.5 & $4.5 \pm 0.7 b$ \\
\hline
\end{tabular}

Means followed by the same letter are not significantly different from each other (Tukey Kramer test, $\mathrm{P}<0.05$ ).

Table 2 - Index of global temperature and humidity (GTHI) and blood cortisol levels of the SS and CS groups

\begin{tabular}{|c|c|c|c|c|}
\hline \multirow{2}{*}{ Treatment } & \multicolumn{2}{|c|}{ GTHI } & \multicolumn{2}{|c|}{ Cortisol $(\mu \mathrm{g} / \mathrm{dL})$} \\
\hline & Maximum & Mean & Maximum & Mean \\
\hline $\mathrm{SS}$ group & 92.0 & $89.1 \pm 2.8 \mathrm{a}$ & 2.4 & $1.9 \pm 0.2 \mathrm{a}$ \\
\hline CS group & 87.6 & $84.7 \pm 2.2 b$ & 2.2 & $1.7 \pm 0.3 b$ \\
\hline
\end{tabular}

Means followed by the same letter are not significantly different from each other (Tukey Kramer test, $\mathrm{P}<0.05$ ). 
Researching the clinical, hematological, biochemical, and hormonal parameters in cattle subjected to heat stress, Ferreira et al. (2009) reported a variation between the seasons of the year $(\mathrm{P}<0.05)$, with higher averages in summer $(4.77 \pm 0.20 \mu \mathrm{g} / \mathrm{dL})$ than winter $(3.01 \pm 0.15 \mu \mathrm{g} / \mathrm{dL})$. Differences $(\mathrm{P}<0.05)$ were also found between sexes, with higher serum levels for females $(4.78 \pm 0.25 \mu \mathrm{g} / \mathrm{dL})$ than for males $(3.60 \pm 0.23 \mu \mathrm{g} / \mathrm{dL})$. The difference between the periods was reported for females only during summer $(\mathrm{P}<0.05)$, when a significant increase was found in cortisol levels in the afternoon $(4.78 \pm 0.25 \mu \mathrm{g} / \mathrm{dL})$. Similarly, it is likely that in the present study the increase in serum cortisol levels between the periods resulted from acute heat stress since this hormone is a stress indicator. Cortisol was not correlated with AT, RH, or the GTHI (Table 3). However, $\mathrm{T}_{3}$ and $\mathrm{T}_{4}$ were negatively correlated with AT and the GTHI $(\mathrm{P}<0.01)$.

These findings reveal that the thyroid hormone levels in the bloodstream markedly decrease (whereas the opposite effect occurs for RH) as AT and the GTHI increase. These results show how important silvopastoral systems are in buffalo farming in hot, high-humidity regions such as the Amazon, since it is known that air temperature under tree canopies can be 2 to $3{ }^{\circ} \mathrm{C}$ below that under full sunlight due to the positive interference of leaves in the passage of solar radiation (Moraes Júnior et al., 2010).

Table 3 - Correlation coefficients between the hormonal and climatic variables in female Murrah buffaloes

\begin{tabular}{lccc}
\hline \multirow{2}{*}{ Variable } & \multicolumn{3}{c}{ Climate variables } \\
\cline { 2 - 4 } & $\mathrm{AT}$ & $\mathrm{RH}$ & $\mathrm{GTHI}$ \\
\hline $\mathrm{T}_{4}$ & $-0.70^{* *}$ & $0.64^{* *}$ & $-0.65^{* *}$ \\
$\mathrm{~T}_{3}$ & $-0.70^{* *}$ & $0.65^{* *}$ & $-0.48^{*}$ \\
Cortisol & $0.22 \mathrm{~ns}$ & $-0.20 \mathrm{~ns}$ & $0.35 \mathrm{~ns}$ \\
\hline
\end{tabular}

AT - air temperature; RH - relative humidity; GTHI - index of globe temperature and humidity.

T4 - thyroxine; T3 - triiodothyronine.

ns - not significant; ** significant at $0.01 ; *$ significant at 0.05 .

\section{Conclusions}

The thermal-stress-indicating hormonal profile of buffaloes - cortisol, $\mathrm{T}_{3}$ and $\mathrm{T}_{4}$ - show that in the less rainy season, the animals are more prone to heat stress. However, higher cortisol levels, also in the rainier season, show the influence of climate on the thermal comfort of these animals. The transition period provides the most adequate climatic conditions for buffalo farming. The high cortisol levels in the animals of the group with no shade reflect the efficiency of the silvopastoral system as compared with the traditional buffalo-farming system in the Eastern Amazon, Brazil.

\section{Acknowledgments}

Thanks to Superintendência de Desenvolvimento da Amazônia (SUDAM), Embrapa Amazônica Oriental, Universidade Federal Rural da Amazônia (UFRA), and the Coordenação de Aperfeiçoamento de Pessoal de Nível Superior (CAPES) for the resources needed to conduct the experiments.

\section{References}

Aggarwal, A. and Singh, M. 2010. Hormonal changes in heat-stressed Murrah buffaloes under two different cooling systems. Buffalo Bulletin 29:1-6.

Bianchin, I.; Koller, W. W. and Detmann, E. 2006. Sazonalidade de Haematobia irritans no Brasil Central. Pesquisa Veterinária Brasileira 26:79-86.

Buffington, D. E.; Colazzo-Arocho, A. and Caton, G. H. 1981. Black globe humidity comfort index (BGHI) as comfort equation for dairy cows. Transaction of the American Society Agricultural Engineering 24:711-714.

Castro, A. C.; Lourenço Júnior, J. B.; Santos, N. F. A.; Monteiro, E. M. M.; Aviz, M. A. B. and Garcia, A. R. 2008. Silvopastoral system in the Amazon region: tool to increase the productive performance of buffaloes. Ciência Rural 38:2395-2402.

Ferreira, F.; Campos, W. E.; Carvalho, A. U.; Pires, M. F. A.; Martinez, M. L.; Silva, M. V. G. B.; Verneque, R. S. and Silva, P. F. 2009. Parâmetros clínicos, hematológicos, bioquímicos e hormonais de bovinos submetidos ao estresse calórico. Arquivo Brasileiro de Medicina Veterinária e Zootecnia 61:769-776.

Garcia, A. R. 2013. Conforto térmico na reprodução de bubalinos criados em condições tropicais. Revista Brasileira de Reprodução Animal 37:121-130.

Garcia, A. R.; Matos, L. B.; Lourenço Júnior, J. B.; Nahúm, B. S.; Araújo, C. V. and Santos, A. X. 2011. Variáveis fisiológicas de búfalas leiteiras criadas sob sombreamento em sistemas silvipastoris. Pesquisa Agropecuária Brasileira 46:1409-1414.

Haque, N.; Ludri, A.; Hossain, S.A. and Ashutosh, M. 2012. Alteration of metabolic profiles in young and adult Murrah buffaloes exposed to acute heat stress. International Journal of Applied Animal Sciences 1:23-29.

Khongdee, T.; Sripoon, S. and Vajrabukka, C. 2011. The effects of high temperature and wallow on physiological responses of swamp buffaloes (Bubalus bubalis) during winter season in Thailand. Journal of Thermal Biology 7:417-421.

Láu, H. D. 1999. Doenças em búfalos no Brasil: diagnóstico, epidemiologia e controle. Embrapa - SPI, Brasília; Embrapa CPATU, Belém.

Marai, I. F. M. and Haeeb, A. A. M. 2010. Buffalo's biological functions as affected by heat stress - A review. Livestock Science 127:89-109.

Morais, D. A. E. F.; Maia, A. S. C.; Silva, R. G.; Vasconcelos, A. M.; Lima, P. O. and Guilhermino, M. M. 2008. Variação anual de hormônios tiroidianos e características termorreguladoras de vacas leiteiras em ambiente quente. Revista Brasileira de Zootecnia 37:538-545.

Moraes Júnior, R. J.; Garcia, A. R.; Santos, N. F. A.; Nahúm, B. S.; Lourenço Junior, J. B.; Araújo, C. V. and Costa, N. A. 2010. Conforto ambiental de bezerros bubalinos (Bubalus bubalis Linnaeus, 1758) em sistemas silvipastoris na Amazônia Oriental. Acta Amazônica 40:629-640.

Moura Carvalho, L. O. D.; Costa, N. A.; Lourenço Júnior, J. B. and Baena, A. R. C. 2001. Cerca elétrica para contenção de animais. Emater, Belém. 
Pachêco, N. A.; Santiago, A. V.; Bastos, T. X. and Cordeiro, A. H. F. 2009. Boletim Agrometerorológico de 2009 para Belém, PA. Documentos, 371. Embrapa Amazônia Oriental, Belém.

Silva, J. A. R.; Araújo, A. A.; Lourenço Júnior, J. B.; Santos, N. F. A.; Garcia, A. R. and Nahúm, B. S. 2011. Conforto térmico de búfalas em sistema silvipastoril na Amazônia Oriental. Pesquisa Agropecuária Brasileira 46:1364-1371.
Starling, J. M. C.; Silva, R. G.; Negrão, J. A.; Maia, A. S. C. and Bueno, A. R. 2005. Variação estacional dos hormônios tireoideanos e do cortisol em ovinos em ambiente tropical. Revista Brasileira de Zootecnia 34:2064-2073.

White, B. A. 2009. Os sistemas endócrino e reprodutor. p.741-744. In: Berne \& Levy: Fisiologia. 6th ed. Koepen, B. M. and Stalon, B. A., eds. Elsevier, Rio de Janeiro. 